\title{
Role of locus of control and family dynamics in academic anxiety of high school students
}

\author{
Neetu Dalal ${ }^{1 *}$, Mohita Gulrajani ${ }^{2}$
}

\section{ABSTRACT}

The current study examined the role locus of control and family dynamics play in academic anxiety of high school students. Locus of Control refers to a personality dimension that enables understanding one's behaviour (Rotter, 1966). Locus of Control seems to play a vital role in Test anxiety defined as "a psychological state of mind characterised by fear and worry" Olatoye and Afuwape (2003). For the purpose of this study, the sample comprised of 30 high school going students randomly chosen from the Government schools of Delhi (Age Range $=15-18$ years). The sample was administered locus of control scale (Anand kumar and Srivastav 1985) and Westside Test Anxiety Scale. The results arrived at through t-test were found to be significantly meaningful in understanding test anxiety as a construct.

\section{Keywords: Locus of Control, Academic anxiety and family dynamics}

$\mathrm{T}$ The performance of a child in academics is generally mapped by the grades or percentage scored on tests. Many factors such as locus of control (Nowicki and Strickland, 1973), test anxiety (Bhatta, 2012), intelligence (Reis \& McCoach, 2000), study habit (Bhatta, 2011) and family dynamics seem to play a role in this academic achievement.

Rotter in 1996 gave the concept of locus of control. Locus of control is defined as the perception of the individual to believe whether events happening around him are controlled internally of externally (Rotter, 1966).

Kirkpatrick, Stant, Downes and Gaither (2008) defined locus of control as a construct indicating how much of an individual's actions are responsible for the things happening around him.

Locus of control are of two types: internal and external. A person having internal locus of control believes that the events happening around him are under his control and his actions impact them. On the other hand, an individual having external locus of control believes that things happening around him aren't in his control and are happening due to other factors such as luck, fate etc.

\footnotetext{
${ }^{1}$ Research Scholar, Department of Psychology, Panjab University, Chandigarh, India

${ }^{2}$ Student, Chaudhary Ranbir Singh University, Jind, Haryana, India

*Responding Author

Received: November 11, 2020; Revision Received: December 20, 2020; Accepted: December 31, 2020

(C) 2020, Dalal N. \& Gulrajani M.; licensee IJIP. This is an Open Access Research distributed under the terms of the Creative Commons Attribution License (www.creativecommons.org/licenses/by/2.0), which permits unrestricted use, distribution, and reproduction in any Medium, provided the original work is properly cited.
} 


\section{Role of locus of control and family dynamics in academic anxiety of high school students}

Individuals having external locus of control have been found to score high on test anxiety as well (Archer, 1979).

Test anxiety is the anxiety an individual experiences either before, during or after the test and is a "situation-specific personality trait" Spielberger,Gonxalez, Taylor and Anton(1978). The physiological responses such as worry, palpitation, increase in heart rate etc. while taking an exam characterise test anxiety Abolghasemi, Asadi, Moghadam, Najarian, \& Shokrkon, 1996; Vitasari, Nubli, Othman, Herrawan, \& Sinnadurai, 2010).

Research has shown that students having higher text anxiety fare poorly in exams (Sena, Lowe and Lee, 2007). An inverse relationship between test anxiety and examination scores have been suggested by previous research by Chapell, Blanding, Siverstein, Takashi, Newman, Gubi and Mccain (2005).

Almost $30 \%$ of the students in school experience test anxiety and this high test anxiety has been found to be correlated with low self-esteem, grades and an intense fear of failure Hembree (1998).

Family dynamics is defined as the environment of the family one lives in. Family dynamics has also been found to be responsible in adding to the anxiety experienced by and individual in life. Research has shown that family dynamics also play a role in test anxiety.

It is important, therefore to explore these variables.

\section{METHODOLOGY}

\section{Statement of purpose}

To study the test anxiety of students belonging to two groups of locus of control.

\section{Objectives}

The study will be conducted with the following objectives:

1. To study the relationship between locus of control and anxiety levels of high school students.

2. To study the relationship between family dynamics and anxiety levels of high school students.

\section{Hypothesis}

1. The internal Locus of the control group are expected to have low anxiety in comparison to external Locus of the Control group.

2. The subjects belonging to the nuclear family dynamic group are expected to score low on anxiety in comparison to joint family subjects.

\section{Sample}

A sample of 30 students in the age group of 15-18 years from various schools of Delhi were taken randomly sampling.

\section{Measures used}

Personal data schedule: Information of the sample such as age, gender, class, family dynamics etc. was collected via this personal data schedule. 
Rotter's Locus of Control Scale: It is the Indian adaption of Julian Rotter's InternalExternal scale by Dr.Anand Kumar and Dr. S.N. Srivastava of Kashi Vidyapith University, Varanasi. It measures an individual's perception of internal / external control of various events. This is a forced choice instrument which consists of 29 pairs of statements; each item has two sentence choices. Subject has to select one statement from each pair which he or she believes more strongly. Scoring is done as per scoring manual and higher scores indicates high externality and vice-versa.

Westside Test Anxiety Scale: is a brief, ten item instruments. The Westside Test Anxiety Scale is an extremely brief screening instrument meant to identify students with anxiety impairments. The scale consists of ten items, and takes about five to eight minutes to administer.

\section{Statistical Technique}

Data was analysed using T-test to examine significant differences between two groups of samples with regard to test anxiety.

\section{DISCUSISION OF RESULTS}

The aim of the study was to assess the role of locus of control and family dynamics in academic anxiety of high school students selected from Delhi schools amid lockdown. The students were administered with locus of control scale along with test anxiety scale. The interpretation was made using t-test. The results of the study are presented in the tables.

Table:1 Mean, SD and t-value of test anxiety of students in two levels of Locus of Control

\begin{tabular}{|l|l|l|l|l|l|}
\hline \multicolumn{2}{|l|}{ Score of LOC } & N & Mean & Std. Deviation & t-value \\
\hline \multirow{2}{*}{$\begin{array}{l}\text { Score of Test } \\
\text { anxiety }\end{array}$} & Internal & 12 & 2.025 & 0.488 & $4.163 * *$ \\
\cline { 2 - 7 } & External & 18 & 2.839 & 0.547 & \\
\hline
\end{tabular}

**significant at 0.01 level

Figure No. 1: Showing mean trends of test anxiety of students in two levels of locus of control

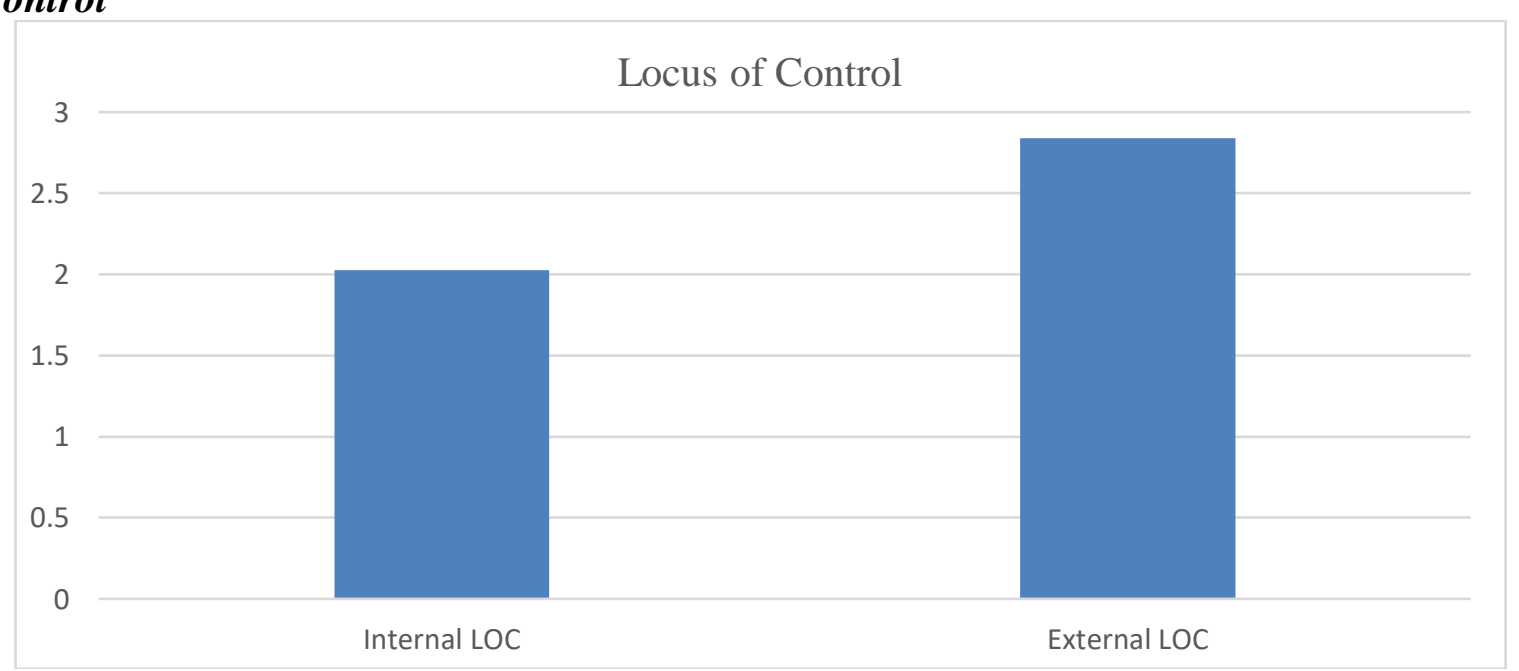

Table: 1 and Fig No. 1 gives means, SDs and t-value of test anxiety of students belonging to two categories of LOC i.e. external LOC and internal LOC. The students with external Locus of control have higher mean score in Test anxiety (2.839) than those students with internal Locus of control (2.025). The t-value are 4.16 which is significant at 0.01 levels. 
This reveals that there exists a significant difference in test anxiety between the two groups of locus of control. Therefore, a person with internal locus of control will experience lesser test anxiety as compared to ones having external locus of control.

This is also supported by various studies in the literature (Archer, 1979; Beekman et al., 2000; Berrenberg, 1987; Gabbard, Howard, \& Tageson, 1986; Moore, 2006; Watson, 1967), which found that internal locus of control is negatively correlated with test anxiety and the higher the internal locus of control, lower will be the test anxiety experienced.

Table 2 Mean, SD and t-value of test anxiety of students in two groups of Family Dynamics

\begin{tabular}{|l|l|l|l|l|l|}
\hline \multicolumn{2}{|l|}{ Type of Family } & N & Mean & Std. Deviation & t-value \\
\hline \multirow{2}{*}{$\begin{array}{l}\text { Score of Test } \\
\text { anxiety }\end{array}$} & Nuclear & 19 & 2.332 & 0.665 & $2.110^{*}$ \\
\cline { 2 - 6 } & Joint & 11 & 2.827 & 0.529 & \\
\hline
\end{tabular}

*significant at 0.05 level

Figure No. 2: Showing mean trends of test anxiety of students in two groups of family dynamics

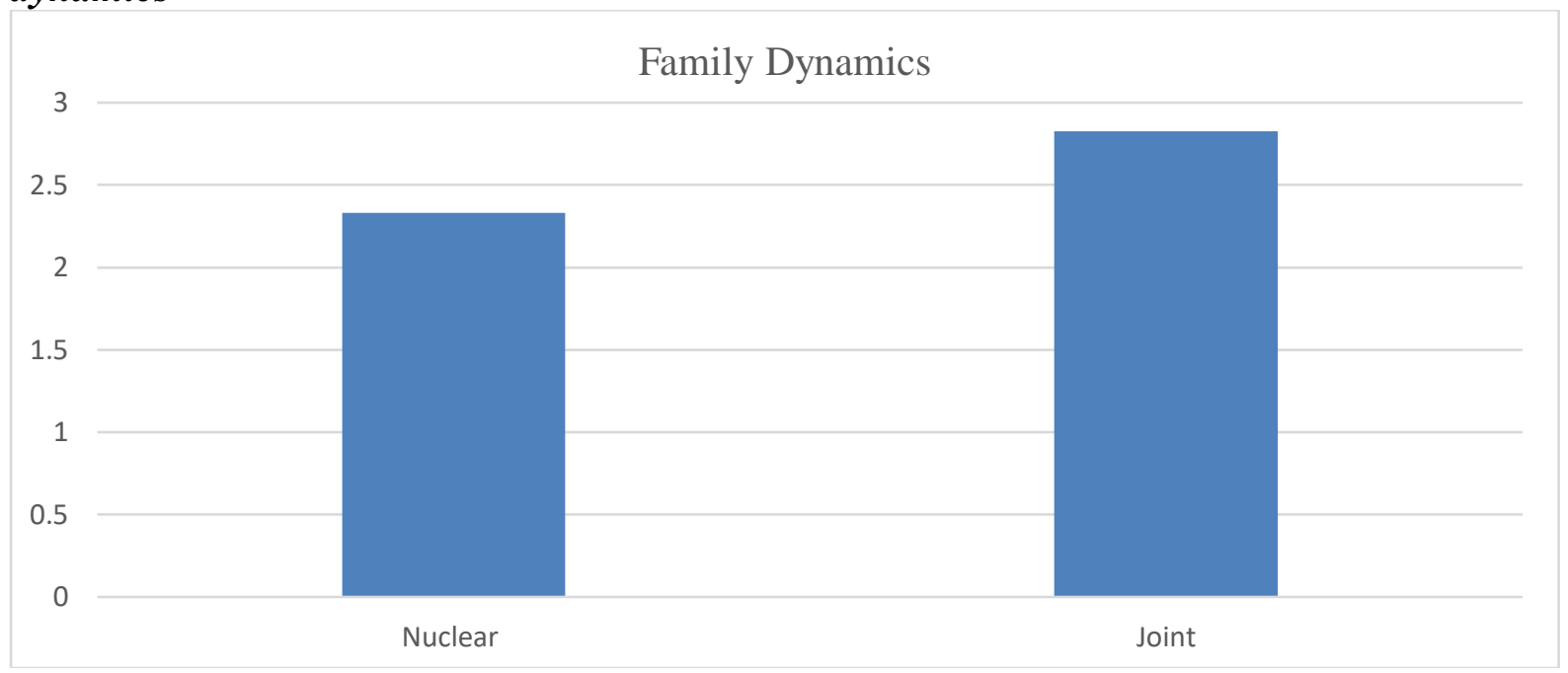

Table: 2 and Fig No. 2 gives means, SDs and t-value of test anxiety of students belonging to two groups of family dynamics i.e., nuclear family and joint family. The students with joint family have higher mean score in Test anxiety (2.827) than those students with nuclear family (2.332). The t-value are 2.11 which is significant at 0.05 levels. This reveals that there exists a significant difference in test anxiety between the two groups of family dynamics. Therefore, a person living in nuclear family dynamics will experience lesser test anxiety as compared to a person living in joint family dynamics.

\section{CONCLUSION}

The following are the conclusions:

1. There is a significant effect of LOC on test anxiety of students: internal LOC students experience lesser test anxiety than external LOC students.

2. There is a significant effect of family dynamic on test anxiety of students: nuclear family students experience lesser test anxiety than joint family students.

The size of the study was small and that's one limitation of the study. In addition, the distribution of students from each locus of control group and family dynamics was not 


\section{Role of locus of control and family dynamics in academic anxiety of high school students}

equal. Further research can expand on the study and include college going students across multiple cities as well. A gender-based comparison can also be fetching in the variables.

\section{REFERENCES}

Abolghasemi, A., Asadi Moghadam, A., Najarian, B., \& Shokrkon, H. (1996). Scale reliability for measurement of test anxiety of Ahwaz's guidance school girls. Journal of Psychological and Educational Sciences of Ahwaz Chamran University, 3, 61-74.

Archer, R. P. (1979). Relationships between locus of control and anxiety. Journal of Personality Assessment, 43, 617-626. doi:10.1207/s15327752jpa4306_10

Bhatta, K.R. (2011). Study habit and academic achievement among master level students. Manaswe. VII, 23-27

Bhatta, K.R.(2012). Test anxiety and academic achievement among students. Psychological studies: Journal of Central Department of Psychology. I (1), 36-38

Chapell, M. S. Blanding, Z. B., Siverstain, M. E., Takashi, M. N. B., Newman, B., Gubi, A. \& Mccain N. (2005). Test anxiety and academic performance in undergraduate and graduate students. Journal of Educational Psychology. 97 (2) 268-274.

Hembree, R. (1988). Correlates, causes and treatment of test anxiety. Review of Educational Research. 58 (1) 47-77

Kirkpatrick, M. A., Stant, K., Downes, S. \& Gaither, L. (2008). Perceived locus of control and academic performance: Broadening the construct's applicability. Journal of College Students Development. 49 (5) 486-496

Nowicki, S., \& Strickland, B. R. (1973). A locus of control scale for children. Journal of Consulting and Clinical Psychology, 40, 148- 154. doi:10.1037/h0033978

Reis, S. M. and McCoach, D. B. (2000). The underachievement of gifted students: What do we know and where do we go? Gifted Child Quarterly, 44, 152-170.

Rotter, J. B. (1966). Generalized expectancies for internal versus external control of reinforcement, Psychology Monographs, 80, 1-28. doi:10.1037/h0092976

Sena, J.D. Lowe, P.A. \& Lee, S.W. (2007). Significant predictors of test anxiety among students with and without learning disabilities. Journal of learning disabilities. 40 (4) 360-376

Spielberger, C. D. (1972). Current trends in theory and research on anxiety. In C. D. Spielberger (Ed.), Anxiety: Current trends in theory and research (pp. 3-9). New York and London: Academic Press.

Vitasari, P., Nubli, A. M., Othman, A., Herrawan, T., \& Sinnadurai, S. K. (2010). The relationship between study anxiety and academic performance among engineering students. Procedia Social and Behavioral Sciences, 8, 490-497. doi: 10.1016/j.sbspro.2010.12.067

\section{Acknowledgement}

The author appreciates all those who participated in the study and helped to facilitate the research process.

\section{Conflict of Interest}

The author declared no conflict of interest.

How to cite this article: Dalal N. \& Gulrajani M. (2020). Role of locus of control and family dynamics in academic anxiety of high school students. International Journal of Indian Psychology, 8(4), 1319-1323. DIP:18.01.144/20200804, DOI:10.25215/0804.144 